\title{
Pola tumor rongga mulut di Rsup Prof.Dr.R.D Kandou Manado periode 2014-2016
}

\author{
${ }^{1}$ Megawati Kanaco \\ ${ }^{2}$ Victor Pontoh \\ ${ }^{2}$ Haryanto Sunaryo
}

\author{
${ }^{1}$ Kandidat Skripsi Fakultas Kedokteran Universitas Sam Ratulangi Manado \\ ${ }^{2}$ Bagian Bedah RSUP Prof. DR. R. D. Kandou Manado \\ Email: Megawatikanaco@yahoo.com
}

\begin{abstract}
Tumor in general terms is a mass or growth of abnormal system in the body. There are 2 types of tumor benign tumors and malignant tumor. Manifestasion can various shape, ranging form small lesion, mass or granulation until the tumor is widespread. Tumor/oral cancer is counted about $2 \%$ from all cancer mortalities are the sixth most common malignabt tumor in the world. Objective researchto determain the pattern of oral cancer at Prof. DR. R. D. Kandou general hospital manado periods 2014-2016. The method use in this research is descriptive retrospective study. Data was collected from medical record in medical record installation and department of the anatomic pathology at Prof. DR. R. D. Kandou general hospital manado periods 2014-2016. This research was found tumor of oral of the period was 67 case. Benign tumor of oral was 27 case and malignant tumor of oral was 40 case.
\end{abstract}

Keywords: tumor of oral, benign tumor of oral, dan malignant tumor of oral.

\begin{abstract}
Abstrak: Tumor dalam istilah umum adalah pertumbuhan massa atau jaringan abnormal dalam tubuh. Tumor terbagi menjadi 2 yaitu tumor jinak dan tumor ganas. Manifestasinya dapat berbagai bentuk, mulai dari lesi kecil, massa atau granulasi sampai dengan tumor yang sudah meluas. Tumor/kanker rongga mulut ditemukan sekitar $2 \%$ dari seluruh keganasan 'merupakan urutan keenam terbanyak dari seluruh tumor ganas yang dilaporkan di dunia. Tujuan penelitian ini adalah Untuk mengetahui pola tumor rongga mulut di RSUP Prof. DR. R. D. Kandou Manado periode 2014-2016. Penelitian yang di laksananakan menggunakan metode penelitian deskriptif retrospektif. Data diambil dari rekam medik di instalasi rekam medik dan bagian patologi anatomi RSUP Prof. DR. R. D. Kandou Manado periode 20142016. Pada penelitian ini di jumpai penderita tumor rongga mulut pada periode tersebut adalah 67 kasus, yang terbagi dari tumor jinak rongga mulut 27 kasus dan tumor ganas rongga mulut 40 kasus.
\end{abstract}

Kata kunci: tumor rongga mulut, tumor jinak rongga mulut, dan tumor ganas rongga mulut.

Tumor adalah massa jaringan yang abnormal, tumbuh berlebihan, tidak terkoordinasi dengan jaringan normal, tumbuh terus menerus meskipun rangsang yang menimbulkan telah hilang, dan tidak dapat dikontrol oleh tubuh. Tumor berdasarkan sifat terbagi menjadi tumor jinak dan tumor ganas. Tumor juga dapat terjadi pada rongga mulut, dimana dapat menyerang lapisan epidermis mukosa mulut, otot, tulang rahang, kelenjar ludah dan kelenjar getah bening. ${ }^{1}$

Tumor ganas rongga mulut merupakan suatu masalah yang serius di berbagai negara bukan hanya dapat menyebabkan kematian, tetapi dapat menyebabkan kerusakan yang luas, kehilangan fungsi, perubahan sikap, kesusahan dalam bentuk 
keuangan dan sosiologi. tumor ganas rongga mulut merupakan $2 \%$ dari semua kasus keganasan yang mengenai manusia. merupakan urutan keenam terbanyak dari seluruh tumor ganas yang dilaporkan di dunia. $^{2}$

Di Amerika satu orang meninggal dalam satu jam, hal itu akibat tumor ganas rongga mulut yang mudah menyebar. ${ }^{2}$ Prevalensi kejadian kanker rongga mulut di Amerika Serikat adalah 2 - 4\% dari semua kanker. Sekitar 28.000 kasus kanker rongga mulut baru dideteksi pada tahun 2007. Kanker rongga mulut adalah kanker kedelapan yang paling sering terjadi pada pria kulit putih dan kanker keenam yang paling sering terjadi pada pria kulit hitam. ${ }^{3}$

Menurut penelitian di Amerika Serikat, pada tahun 2011 sekitar 7.900 kematian terjadi yang diakibatkan oleh tumor ganas rongga mulut dengan lebih dari $90 \%$ adalah squamous sel karsinoma. ${ }^{4}$ Di India khususnya di Kerala kejadian tumor ganas rongga mulut sangat tinggi yaitu sekitar $20 \%$ dari seluruh keganasan. ${ }^{5}$

Di Indonesia kasus tumor ganas rongga mulut berkisar 3-4\% dari seluruh kasus keganasan yang terjadi dengan etiologi tumor yang sangat beragam (multifaktorial). ${ }^{6}$ Angka kematiannya yaitu 2-3\% dari seluruh kematian akibat keganasan.

Prevalensi nasional tumor/kanker rongga mulut di Indonesia tahun 2007 adalah $0,4 \%$. Sebanyak 9 provinsi mempunyai prevalensi penyakit tumor/kanker diatas prevalensi nasional yaitu Sumatera Barat, DKI Jakarta, Jawa Barat, Jawa Tengah, Yogyakarta, Banten, Bali, Sulawesi Utara, dan Sulawesi Selatan. ${ }^{7}$

Berdasarkan penelitian sebelumnya di RSUP Sanglah Denpasar Bali diperoleh 105 kasus tumor rongga mulut pada periode tersebut, 56 kasus tumor jinak rongga mulut dan 49 kasus tumor ganas rongga mulut. Prevalensi diagnosis akhir tertinggi untuk tumor jinak rongga mulut adalah Ameloblastoma 28 kasus (50\%).

Prevalensi diagnosis akhir tertinggi untuk tumor ganas rongga mulut adalah
Squamous cell carcinoma atau karsinoma sel skuamosa sebanyak 27 kasus $(55,1 \%)$. Prevalensi penderita laki-laki lebih tinggi dari penderita perempuan yaitu 30:19. Prevalensi berdasarkan kelompok usia tertinggi terjadi pada kelompok usia 41-50 tahun dan terapi yang paling banyak digunakan sebagai pilihan perawatan adalah terapi pembedahan baik untuk tumor jinak maupun tumor ganas rongga mulut. ${ }^{1}$

Berdasarkan hal tersebut peneliti tertarik untuk mempelajari dan meneliti lebih lanjut mengenai pola tumor rongga mulut di RSUP Prof. DR. R. D. Kandou Manado periode tahun 2014 sampai dengan tahun 2016 bedasarkan angka kejadian, umur, jenis kelamin, dan jenis histopatologi.

\section{METODE PENELITIAN}

Penelitian yang dilakukan bersifat deskriptif restrospektif dengan mengambil data sekunder di Instalasi Rekam Medik dan bagian Patologi Anatomi, penelitian ini dilakukan pada bulan Oktober sampai November 2016. Sampel penelitian adalah pasien tumor rongga mulut jinak maupun ganas di RSUP Prof. DR. R. D. Kandou Manado periode tahun 2014 sampai dengan tahun 2016.

\section{HASIL PENELITIAN}

Berdasarkan penelitian yang di lakukan dibagian rekam medic dan patologi anatomi RSUP Prof. Dr.R.D kandou di dapatkan data kasus tumor rongga mulut periode 2014-2016 adalah sebanyak 67 kasus, Yang terdiri dari 27 kasus kasus tumor jinak rongga mulut dan 40 tumor ganas rongga mulut.

Tabel 1. Angka kejadian tumor rongga mulut menurut tahun di RSUP Prof.DR.R.D Kandou Manado.

\begin{tabular}{l|l|l|l}
\hline Periode & $\begin{array}{l}\text { Tumor } \\
\text { Jinak }\end{array}$ & $\begin{array}{l}\text { Tumor } \\
\text { Ganas }\end{array}$ & Jumlah \\
\hline 2014 & $8(12 \%)$ & $14(20,8 \%)$ & $22(33 \%)$ \\
2015 & $10(15 \%)$ & $15(22,3 \%)$ & $25(37,3 \%)$ \\
2016 & $9(13,4 \%)$ & $11(16,4 \%)$ & $20(29,7 \%)$ \\
Total & $27(40,4)$ & $40(59,5 \%)$ & $67(100 \%)$ \\
\hline
\end{tabular}


Dari data tersebut diperoleh kasus tumor rongga mulut pada periode 2014 sebanyak 22 kasus (33\%) periode 2015 sebanyak 25 kasus $(37,3 \%)$, dan periode 2016 sebanyak 20 kasus $(29,8 \%)$.

Tabel 2. Distribusi Penderita Tumor Rongga Mulut Menurut Umur

\begin{tabular}{l|l|l|l|l|c|l}
\hline \multirow{2}{*}{ Umur } & \multicolumn{2}{|l|}{ Tumor jiank } & \multicolumn{2}{l|}{ Tumor ganas } & \multirow{2}{*}{ JUMLAH } & \% \\
\cline { 2 - 5 } & $\mathbf{N}$ & $\mathbf{\%}$ & $\mathbf{N}$ & $\mathbf{\%}$ & & \\
\hline$\leq 20$ & 4 & $(6,0 \%)$ & 2 & $(3,0 \%)$ & 6 & $(9.0 \%)$ \\
$21-30$ & 2 & $(3,0 \%)$ & 4 & $(6,0 \%)$ & 6 & $(9.0 \%)$ \\
$31-40$ & 1 & $(1,4 \%)$ & 2 & $(3,0 \%)$ & 3 & $(4,4 \%)$ \\
$41-50$ & 8 & $(12.0 \%)$ & 12 & $(18,0 \%)$ & 20 & $(30,0 \%)$ \\
$51-60$ & 7 & $(10,4 \%)$ & 8 & $(12.0 \%)$ & 15 & $(22,4 \%)$ \\
$61-70$ & 2 & $(3,0 \%)$ & 7 & $(10,4 \%)$ & 9 & $(13,4 \%)$ \\
$>70$ & 3 & $(4,4 \%)$ & 5 & $(7,4 \%)$ & 8 & $(12.0 \%)$ \\
Total & 27 & $40,2 \%$ & 40 & $59,8 \%$ & 67 & $100 \%$ \\
\hline
\end{tabular}

Berdasarkan Tabel di atas dapat di lihat frekuensi penderita tumor rongga mulut menurut umur. Golongan umur $>20$ tahun sebanyak 6 orang $(9,0 \%)$, dimana 4 orang $(6,0 \%)$ tumor jinak rongga mulut dan 2 orang $(3,0 \%)$ tumor ganas rongga mulut.Golongan umur 21-30 tahun sebanyak 6 orang $(9.0 \%), 2$ orang $(3,0 \%)$ tumor jinak rongga mulut dan 4 orang $(6,0 \%)$ tumor ganas rongga mulut. Golongan umur 31-40 tahun sebanyak 3 orang $(4,4 \%), 1$ orang $(1,4 \%)$ tumor jinak rongga mulut, 2 orang $(3,0 \%)$ tumor ganas rongga mulut. Golongan umur 41-50 sebanyak 20 orang $(30,0 \%), 8$ orang (12.0\%) tumor jinak rongga mulut dan 12 orang $(18,0 \%)$ tumor ganas rongga mulut. Golongan umur 51-60 tahun sebanyak 15 orang $(22,4 \%), 7$ orang $(10,4 \%)$ tumor jinak rongga mulut dan 8 orang $(12.0 \%)$ tumor ganas rongga mulut. Golongan umur 61-70 tahun sebanyak 9 orang $(13,4 \%), 2$ orang $(3,0 \%)$ tumor jinak rongga mulut dan 7 orang $(10,4 \%)$ tumor ganas rongga mulut. Golongan umur $<70$ tahun sebanyak 8 orang $(12,0 \%), 3$ orang $(4,4 \%)$ tumor jinak rongga mulut dan 5 orang $(7,4 \%)$ tumor ganas rongga mulut.

Tabel 3. Distribusi Penderita Tumor Rongga Mulut Menurut Jenis Kelamin

\begin{tabular}{l|l|l|l|l|l|l}
\hline \multirow{2}{*}{ Jenis Kelamin } & \multicolumn{2}{l|}{$\begin{array}{l}\text { Tumor } \\
\text { Jinak }\end{array}$} & \multicolumn{2}{l|}{ Tumor Ganas } & \multirow{2}{*}{ jumlah } & \multirow{2}{*}{} \\
\cline { 2 - 5 } & N & \% & N & \% & & \\
\hline Laki-Laki & 14 & $21 \%$ & 29 & $43,2 \%$ & 43 & $64,1 \%$ \\
Perempuan & 13 & $19 \%$ & 11 & $16,4 \%$ & 24 & $36 \%$ \\
Total & 27 & $40 \%$ & 40 & $59,8 \%$ & 67 & $100 \%$ \\
\hline
\end{tabular}

Berdasarkan Tabel tersebut penderita tumor rongga mulut dengan jenis kelamin laki-laki yaitu sebanyak 43 orang $(64,1 \%)$ dimana 14 orang $(21 \%)$ merupakan tumor jinak rongga mulut, dan 29 orang $(43,2 \%)$ merupakan tumor ganas rongga mulut. sedangakan perempuan sebanyak 24 orang $(36 \%)$ dimana 13 orang $(19,4 \%)$ merupakan tumor jinak rongga mulut, dan 11 orang $(16,4 \%)$ merupakan tumor ganas rongga mulut.

Dari Tabel 4 dapat dilihat distribusi 
frekuensi penderita tumor rongga mulut jinak menurut jenis Patologi anatomi. Jumlah penderita tumor jinak rongga mulut dengan jenis patologi anatomi papiloma yaitu sebanyak 4 kasus $(6,0 \%)$, granular yaitu sebanyak 6 kasus $(9,0 \%$, polip yaitu sebanyak 1 kasus $(1,4 \%)$, adenoma yaitu sebanyak 2 kasus $(3,0 \%)$, muycocele yaitu sebanyak 2 kasus $(3,0 \%)$ dan yang lain-lain sebanyak $12(18,0 \%)$.

Tabel 4. Distribusi Tumor Jinak Rongga Mulut Menurut Jenis Patologi Anatomi

\begin{tabular}{c|c|c}
\hline $\begin{array}{c}\text { Hasil Patologi } \\
\text { Anatomi }\end{array}$ & $\begin{array}{c}\text { Jumlah } \\
\text { Penderita }\end{array}$ & Presentase \\
\hline Papiloma & 4 & $6,0 \%$ \\
Granular & 6 & $9,0 \%$ \\
Polip & 1 & $1,4 \%$ \\
Adenoma & 2 & $3,0 \%$ \\
Muycocele & 2 & $3,0 \%$ \\
Lain-lain & 12 & $18,0 \%$ \\
\hline
\end{tabular}

Dari Tabel 5 dapat dilihat distribusi frekuensi penderita tumor ganas rongga mulut menurut jenis Patologi anatomi. Jumlah penderita tumor ganas rongga mulut dengan jenis patologi anatomi SCCyaitu sebanyak 17 kasus (25,3\%), Malignansia yaitu sebanyak 1 kasus $(1,4 \%)$, basalioma 3 kasus $(4,4 \%)$ dan Lain-lain 19 kasus $(28,3 \%)$.

Tabel 5. Distribusi Tumor Ganas Rongga Mulut Menurut Jenis Patologi Anatomi

\begin{tabular}{c|c|c}
\hline $\begin{array}{c}\text { Hasil } \\
\text { Patologi } \\
\text { Anatomi }\end{array}$ & $\begin{array}{c}\text { Hasil } \\
\text { Patologi } \\
\text { Anatomi }\end{array}$ & Presentase \\
\hline SCC & 17 & $25,3 \%$ \\
Malignansia & 1 & $1,4 \%$ \\
Basalioma & 3 & $4,4 \%$ \\
Lain-lain & 19 & $28,3 \%$ \\
\hline
\end{tabular}

\section{BAHASAN}

Berdasarkan hasil peneitian yang bersifat deskripsif dapat di temukan tumor rongga mulut di bagian rekam medik dan patologi anatomi RSUP Prof.Dr.R.D Kandou manado periode 2014-2016 sebanyak 67 kasus, yang terdiri dari 27 kasus kasus tumor jinak dan 40 tumor ganas. Distribusi frekuensi berdasarkan tahun meningkat pada periode 2015 yaitu 2015 sebanyak 25 kasus (37,3\%). selanjutnya terbanyak kedua disusul oleh periode 2014 sebanyak 22 kasus (33\%). Dan angka kejadian terkecil pada periode 2016 sebanyak 20 kasus (29,8\%). Peningkatan dan penurunan pertahun tumor rongga mulut tidak jauh berbeda setiap tahunnya.

Angka kejadian sebanyak 67 kasus ini lalu dibagi ke dalam distribusi frekuensi menurut umur, jenis kelamin, tempat tinggal, dan jenis histopatologi. Berdasarkan tabel penggolongan umur, tumor rongga mulut terbanyak adalah golongan umur 41-50 tahun sebanyak 20 penderita (30,0\%), Di susul oleh golongan umur 51-60 tahun yaitu sebanyak 15 orang (22,4\%), kemudian Golongan umur 61-70 tahun sebanyak 9 orang $(13,4 \%)$ dan golongan usia $>70$ tahun sebanyak 8 orang $(12,0 \%)$. Hal ini sesuai dengan penelitian Ika Puji Lestari (2011) yang menyatakan bahwa Prevalensi berdasarkan kelompok usia tertinggi terjadi pada kelompok usia 41-50 tahun. ${ }^{1}$ berbeda yang di katakan oleh Tjakra Wibawa Manuaba (2010) Usia median penderita kanker rongga mulut adalah 60 tahun, tetapi angka insiden pada penderita muda ( $<40$ tahun) terus meningkat, terutama didominasi oleh kanker dari lidah. ${ }^{8}$

Dari data pada tabel penggolongan jenis kelamin penderita tumor rongga mulut terbanyak adalah laki-laki yaitu sebanyak 43kasus $(64,1 \%)$, sedangkan perempuan sebanyak 24 kasus (36 \%). Hal itu sesuai dengan penelitian sebelumnya Ika Puji Lestari (2011), yang menyatakan bahwa prevalensi penderita laki-laki lebih tinggi dari pada penderita perempuan. ${ }^{1}$ Hal itu di sebabkan lebih banyak laki-laki yang mengkonsumsi tembakau dalam bentuk merokok di bandingan perempuan. Menurut Depkes RI 2004, prevelensi merokok pada laki-laki sebesar 62,2\% dan perempuan sebesar 1,3\%. Rizkia (2011) menyatakan rokok mengandung bebagai jenis toksin dan agen karsinogen yang dapat membahayakan. ${ }^{9}$ 
Dari Tabel distribusi penderita tumor rongga mulut berdasarkan jenis histopatologi, Penderita dengan tumor jinak rongga mulut terbanyak adalah jenis histopatologi ameloblastoma tipe granular setelah itu diikuti dengan papiloma, adenoma, muycocele, dan yang terendah polip. Hal itu sesuai Syafriadi ${ }^{6}$ bahwa amelosblastoma merupakan yang paling umum di jumpai pada tumor jinak rongga mulut. ${ }^{6}$ dan juga sesuai dengan penelitian Lestari ${ }^{1}$ pada penelitiannya di dapatkan jenis terbanyak untuk tumor jinak rongga mulut adalah ameloblastoma.

Dari Tabel distribusi penderita tumor rongga mulut berdasarkan jenis histopatologi, Penderita dengan tumor ganas rongga mulut terbanyak adalah jenis squamous cell carcinoma atau karsinoma sel skuamosa, lalu diikut dengan dengan jenis basalioma, yang terendah adalah jenis malignansia. Hal itu sesuai dengan penelitian sebelumnya oleh Ika Puji (2011) di dapatkan pada penelitiannya untuk jenis histopatologi tertinggi tumor ganas ronga mulut adalah jenis squamous cell carcinoma atau karsinoma sel skuamosa. ${ }^{\mathbf{1}}$. Hal itu juga sesuai dengan dinyatakan Syafriadi yaitu squamous cell carcinoma merupakan tumor ganas yang tersering terjadi pada rongga mulut biasanya secara klinis terlihat sebagai plak keratosis, ulserasi, tipe lesi yang indurasi, dan kemerahan, di mana SCC dapat terjadi pada seluruh permukaan rongga mulut, paling umum dijumpai hingga $90 \%$ kasus. ${ }^{6}$ pada penelitian di Amerika Serikat juga oleh Langevin SC et al. pada tahun 2011 sekitar 7.900 kematian terjadi diakibatkan oleh kanker rongga mulut dan $>90 \%$ ialah squamous sel karsinoma. ${ }^{4}$

\section{SIMPULAN}

Tumor rongga mulut paling banyak di RSUP Prof. Dr.R.D Kandou Manado periode 2014-2016 adalah tumor ganas rongga mulut dengan jenis histopatologinya squamous cell carcinoma atau karsinoma sel skuamosa,dengan golongan umur terbanyak yaitu 41-50 tahun, jenis kelamin paling banyak adalah laki-laki.

\section{DAFTAR PUSTAKA}

1. Lestari IP. Prevalensi Tumor Jinak dan Tumor Ganas Rongga Mulut di RSUP Sanglah Denpasar Bali berdasarkan Usia, Jenis Kelamin dan Terapi Periode 2009-2010. Jurnal. Universitas Jember. Jawa Timur. 2011

2. Sirait AM. Faktor Resiko Tumor Mulut dan Tenggorokan di Indonesia. Jurnal Media Litbangkes. 2013;23(3).

3. Messadi DV, Wilder-Smith P, Wolinsky L. Improving oral cancer survival: the role of dental providers. J Calif Dent Assoc. 2009;37(11):789-98.

4. Langevin SC, Michaud DS, Elliot M, Peters ES, McClean MD, Kelsey KT. Regular dental visits are associated with earlier stage at diagnosis for oral and pharyngeal cancer. Cancer Causes Control. 2012; 23(11): 1821-29.

5. Balaram P, Meenattoor G. Imunology of Oaral Cancer - A Review. Singapore Dental Journal. 1996;21(1):36.

6. Syafriadi M. Patologi Mulut Tumor Neoplastik, \& Non Neoplastik Rongga Mulut. Yogyakarta: Penerbit Andi, 2008.

7. Sirait AM. Faktor Resiko Tumor Mulut dan Tenggorokan di Indonesia. Jurnal Media Litbangkes. 2013;23(3).

8. Manuaba TW. Panduan penatalaksanaan kanker solid Peraboi 2010. Jakarta: Sagung Seto, 2010; p. 98-100, 104-8.

9. Kusuma PRA. Pengaruh Merokok Terhadap kesehatan Gigi dan Rongga Mulut. Jurnal Fakultas Kedokteran gigi Universitas Islam Sultan Agung. 2011. 